\title{
MEAD, BEHAVIORISM AND INDETERMINACY
}

\author{
Dmitri N. Shalin* \\ Southern Illinois University at Carbondale
}

Schleiermacher once said that every interpretation is the best. I would add, provided the interpreter understands that his is an interpretation, not the final statement of whatever it is that one seeks to interpret. Collins' wide-ranging and provocative essay (to which I cannot do full justice here) on Mead generally avoids imposing on us the definitive reading of Mead. The author correctly points out that "we have a legitimate choice between the various intellectual elements in Mead." Still, I would like to take issue with Collins' choice. Not because it does not have merit, but because it leaves out what I believe to be most important and original in Mead's writings.

Collins variously refers to Mead's outlook as "reductionist," "utilitarian," " naturalistic," "individualistic," and at some point designates it as " "vulgar' behaviorism." True, Mead often used the adjective "behaviorist" in describing his social psychology. He also had close personal ties with John Watson, the founder of behaviorist psychology. Yet, I think it is misleading to call his general stance "behaviorism," since Mead's usage of the term differed so much from the one championed by Watson. Watson sought to expunge all references to psychic phenomena from psychological discourse, substituting for them the description of overt behavior, stimulus situation, conditioning, and so forth. It is an article of faith with him that all responses can ultimately be reduced to and predicted from antecedent stimuli. By contrast, Mead not only affirmed the legitimacy of such concepts as "image," "self," "consciousness," "thought," but also postulated unpredictability and novelty as generic features of human conduct. Mead explicitly warned his students not to confuse his position with Watson's: "John B. Watson's attitude was that of the Queen in Alice in Wonderland - 'Off with their heads!'-there were no such things. There was no imagery, and no consciousness... . The behaviorism which we shall make use of is more adequate than that of which Watson makes use" (Mead 1934, pp. 3, 2). Along with other pragmatists, Mead rejected introspectionism and urged the genetic primacy of action over thought, but this hardly makes him a behaviorist. "Social psychol-

*Direct all correspondence to: Dmitri N. Shalin, Department of Sociology, Southem Illinois University, Carbondale, Il 62901.

Symbolic Interaction, Volume 12, Number 1, pages 37.41.

Copyright $\odot 1989$ by JAI Press Inc.

All rights of reproduction in any form reserved.

ISSN: 0195-6086. 
ogy," explained Mead (1934, p. 7) "is behavioristic in the sense of starting off with an observable activity - the dynamic, ongoing social process, and the social acts which are its component elements-to be studied and analyzed scientifically. But it is not behavioristic in the sense of ignoring the inner experience of the individual-the inner phase of this process or activity" (Mead 1934, p. 7). If this behaviorism is "vulgar," then which kind is not?

It is equally questionable whether Mead's position can be described as "utilitarian." Collins charges that "Mead always has in mind a crude physical response (pounding a nail with a hammer, etc.)" and pictures "a flat, uni-dimensional world [in which] utilitarian actions of individuals are primary." I beg to differ. Opening up drawers and hammering in nails are not the only types of actions analyzed by Mead. One finds in his writings a far greater range of human activities, including interchange between mother and child, the scientific inquiry into the causes of infectious disease, the team work of the players in a baseball game, the quest for a religious community, as well as the reformers' efforts to reconcile the conflicting claims of labor and capital. These undertakings are neither "utilitarian" nor "individualistic." Indeed, I would argue that Mead's stance is inimical to utilitarianism and individualism, insofar as he assumes the primacy of the collective over the individual, gives precedence to interaction over action, and treats the experience of physical reality as a fundamentally social affair: "The physical object is an abstraction that we make from the social responses to nature.... We are not, in social psychology, building up the behavior of the social group in terms of the behavior of the separate individuals composing it; rather, we are starting with a given social whole, into which we analyze (as elements) the behavior of each of the separate individuals composing it ... the whole (society) is prior to the part (the individual), not the part to the whole" (Mead 1934, pp. 184, 7). If this is individualism, I challenge Collins to define collectivism.

Perhaps, it would be useful to make a distinction that remains implicit in Mead's writings and that sometimes causes confusion. There are three different perspectives in Mead's analysis, each calling for a different theoretical emphasis: phylogenetic, ontogenetic, and what for the lack of a better term I call "sitogenetic" (from the Latin "situs"--place or situation). We cannot make recourse to other selves or minds when we deal with the evolutionary origins of consciousness: This would simply presuppose what needs to be explained. Nor can one invoke society in such a phylogenetic inquiry, for society does not exist qua human society yet. ${ }^{2}$ It is quite natural to stress here the evolutionary continuity between animal and human behavior, which is what Mead does when he carries out analysis on this plane, using concepts such as "attitude," "gesture," "conversation of gestures," and so forth. In the ontogenetic perspective, which covers the genesis of individual consciousness within the already established human community, one can legitimately refer to "organized others," "significant symbols," "institutions," and so forth, insofar as these phenomena precede any particular individual and form the necessary background of one's growth into a full-fledged member of society. Finally, when we want to understand how a specific line of action and a peculiar self have evolved in a given situation, that is, when the inquiry proceeds on the sitogenetic plane, we presuppose a fully developed mechanism of self-reflective behavior and employ concepts such as "self-interaction," "I" and "Me," "reconstruction," and so forth. Mead often 
switches from one level of analysis to another, and does so without warning, leading his interpreters to mistake part for whole. Hence, the tendency of some of Mead's commentators to emphasize behavior over consciousness, action over interaction, or self over society. A more productive tack, in my view, is to accept that each emphasis has its place and that the researcher's perspective may determine which one is to be made.

Another point on which I disagree with Collins concerns the issue of idealism and indeterminacy. Collins rightly points out that idealist themes played an important role in Mead's thinking and that they are primarily responsible for his rejection of rigid determinism. I cannot accept his judgment that Mead's "anti-determinist theoretical stance" is a vestige of idealism contrary to science. "Although he sometimes played idealist themes," Collins writes about Mead, "he was also an advocate of science." This sounds to me like a non-sequitur. The statement flies in the face of the avowedly idealist and indeterminist pronouncements of the leading twentieth-century scientists, especially those who devoted their life to microphysics. When the exponents of quantum mechanics assert that "no sharp separation between object and subject can be maintained [because] we are both onlookers and actors in the great drama of existence" (Bohr 1934, pp. 96, 119); when they concede that "the metaphysical hope of classical physicists to gain through science a solid hold on being itself collapses" (Weizsacker 1949, p. 200); and when they wonder, "May the universe in some strange sense be "brought into being' by the participation of those who participate?" (Wheeler, quoted in Zukav 1979, p. 54), they sure sound like idealists, yet this hardly makes them less scientific. Nor does their acceptance of the irreducible element of novelty, unpredictability and indeterminacy in the physical world make them antideterminists. What they reject is classical determinism with its unrealistic expectations concerning the predictability and orderliness of natural events. Mead and his contemporary followers are on solidly scientific grounds when they accept the principle of subject-object relativity and reject this form of determinism. ${ }^{3}$

"When one comes in contact with social phenomena," Durkheim ([1897] 1964, p. 94) used to marvel, "one is surprised with the astonishing regularity with which they occur under the same circumstances. Even the most minute and the most trivial practices recur with the most astonishing uniformity." By contrast, interactionists accentuate "the ubiquitously ambiguous character of modern situations" (Lofland 1976, p. 26), "the world that is varied, changeable, uncertain and conflictful" (Douglas 1977, p. 14). I can understand Collins' desire to complement Meadian analysis with the Durkheimian notion of social constraint and regularity (interactionists need to grapple more directly with this facet of social life). But by imbuing Mead with a hefty dosage of Durkheimian rationalism, Collins runs the risk of losing something precious in the process. The Durkheimian emphasis on determinism, predictability and the externality of social facts, which Collins finds so congenial, is consistent with classical science. The position of Mead and interactionism is more in tune with the outlook of nonclassical science, which accepts the objective nature of uncertainty and underscores the vital role of chaos and dissipative processes in nature. ${ }^{4}$ The interactionist perspective should not be equated with indeterminism (which would indeed make scientific inquiry superfluous); rather, it implies that the world around us is neither fully rational nor entirely absurd, that its status as an objectively meaningful whole is problematic. Sized up in this perspective, society transpires as semiordered chaos (or if you wish, semi-chaotic order), with determinacy being an artifact -a 
practical social accomplishment. Patterned manifestations of social life are not thereby discarded; the attention is simply refocused on the patterns of uncertainty and structures of indeterminacy, that is, on the regular, predictable features in the process of terminating indeterminacy.

There is little room left for comments on Collins' "sociology of thinking," which combines the Meadian perspective on thought as intemalized discourse with Goffman's notion of interaction ritual. Let me make just a few brief remarks.

I find a bit jarring the author's view of thinking as "fantasy play of membership inside one's mind." The persistent emphasis on thought process as "a maneuvering for the best symbolic pay-off" and intellectual creativity as "negotiating one's membership in intellectual coalitions" strikes me as a kind of sociological utilitarianism. There is a lot more to innovative thinking than the attempt to improve one's social standing, and even where the status motive is a factor, it can hardly explain why the individual chose a particular line of inquiry. I am also not sure whether Collins offers us a "sociology of thinking" or "sociology of talking." Somehow, the two appear to be conflated in his discussion. If it is the sociology of thinking that the author is after, does he intend to get inside the individual to grasp what he really thinks? Goffman's inquiry focused on the self's external manifestations - on the presentation of self; but then it emphasized multiple identities and the situational inconstancy of human conduct. Collins' sociology of thinking leaves undefined the method of getting at thought process, and it makes no explicit provision for the multivocity of creative thought. Finally, I could not help thinking that the proposed synthesis of Mead and Goffman leaves out something very important, something that makes us admire both writers. The strength of Mead is in his philosophical acumen, in the dialectical abstractions that boldly weld together self and society, process and structure, agency and objectivity. The power of Goffman is in his marvelous sense of time and place, in his thick description measured by disciplined generalizations. Both of these qualities are somehow lost in Collins' synthesis. I find statements like "what someone thinks about is determined by their recent experience in IRs, and by the interactions which they anticipate most immediately for the future," plausible, though not entirely enlightening. But then, I am sure, others may disagree with my assessment.

To conclude, I wish to emphasize that Collins has every right to choose from Mead's writings what he finds most appealing and thought provoking. If Schleiermacher is right, his interpretation is still the best. Whether it can generate a viable line of research, however, is another matter. Only the future can tell.

\section{NOTES}

1. See Fine and Kleinman (1986) on various readings of Mead.

2. According to Mead (1982, p. 149), "society can exist ... without the emergence of selves, like with the bees and the ants"; however, as Mead (1934, p. 227) explains elsewhere, "human society as we know it could not exist without minds and selves, since all its most characteristic features presuppose the possession of minds and selves by its individual members."

3. Mead's idealism, I might add, is akin to that of the young Marx, when the latter criticized Feuerbach's materialism for its failure to understand objective reality subjectively, that is, as practice. It is also wholly inconsistent with the behaviorist stance which presupposes the ontological primacy of stimulus over response. Mead's pragmatist position, first enunciated in Dewey's article 
on the reflex-arc concept in psychology, is that there is no stimulus apart from the subject, who carves it out from the environment and uses it as a guide for his or her action.

4. The interactionist preoccupation with defining the situation fits perfectly with the epistemological concerns of quantum mechanics. To define the situation is "to terminate the state of indeterminacy"-literally, to supply terms in which the situation could be accounted for as objective and meaningful. Human self, correlatively, appears here as a quantum of social reality objectified in a given situation; it can exist in many different objective states, none of which is more real than the other, and any one of which is rooted in a specific measurement context.

\section{REFERENCES}

Bohr, Niels. 1934. Atomic Theory and Description of Nature. New York: The Macmillan Company. Douglas, Jack D. 1977. "Existential Sociology," pp. 3-73 in Jack D. Douglas and John M. Johnson, eds., Existential Sociology. Cambridge: Cambridge University Press.

Durkheim, Emile. [1897] 1964. The Rules of Sociological Method. New York: Free Press.

Fine, Gary A. and Sherryl Kleinman. 1986. "Interpreting the Sociological Classics: Can There be 'True' Meaning of Mead?" Symbolic Interaction 9: 129-146.

Lofland, John. 1976. Doing Social Life: The Qualitative Study of Human Interaction in Natural Settings. New York: John Wiley and Sons.

Mead, George H. 1934. Mind, Self and Society. Chicago: University of Chicago Press.

1982. Individual and the Social Self. Chicago: University of Chicago Press.

Weizsacker, Carl Friedrich von. 1949. The World View of Physics. Chicago: University of Chicago Press.

Zukav, Gary. 1979. The Dancing Wu-Li Masters. An Overview of the New Physics. New York: William Morrow \& Co. 